\title{
Security vs. Fear
}

\author{
By JACOB HøIGILT
}

"But what's the alternative to the current regime? Aren't we at least better than Syria and Iraq?" (NA'ĪM) The op-ed in one of Egypt's few remaining independent media outlets captures the general political mood well: the atmosphere is characterized by fear on the one hand and a sense that the regime is the guarantor for security on the other.

There is plenty of fear among ordinary people. The biggest is perhaps the fear of the Other in its many guises. Egypt's Copts feel very insecure, but mostly suffer in silence, afraid that speaking out will only lead to a backlash. However, after several violent incidents in the Upper Egyptian municipality of al-Minyā, including one where an elderly woman is stripped naked and dragged through the streets, some raise their voices and demonstrate on August 13 with banners saying:

"Christians are being persecuted," "Christians are Egyptians," "No to pressuring victims to reconcile," and "No to state institutions' collusion in sectarian violence." (MY)

At the other end of the religious divide, some Egyptian Muslims regard $\nearrow$ Conversions as an existential threat to Egypt's social fabric, and the Copts are sometimes cast as would-be traitors conspiring with sinister Western powers to weaken Egypt [ $\nearrow$ The Suspect Foreigner, $\lambda$ True $=$ False $($ Life in Limbo) $]$. The religious tension and the system of fear that underlies it are treated in the movie Mawlāna (The Preacher), which is screened at the Dubai International Film Festival and creates a stir in Egypt because of its liberal message about cross-religious tolerance. The well-known analyst of religious politics, Rafĩ Habīb, offers a bleak view in an interview with Counterpunch in December:

The most worrying problem in Egypt is the prejudice on both sides which has grown over the last 25 years and is still growing... The Copts are the ones who feel it, because they're the minority; and the government is unable to deal with it. (KRISTIANASEN)

Fear of the Other is also on prominent display in the continuing polarization between those who support the now outlawed Muslim Brothers and those who mistrust or even hate the organization, believing it to aim for the establishment of an Iranian-like Islamic state. When the movie Ishtibāk (Clash) is released, its message of tolerance across the secularist-Islamist divide prompts several movie theaters to refuse to screen it. Director Muhammad Diyāb is accused of wanting to hurt Egyptian interests to the benefit of foreigners [ $\nearrow \mathrm{Clash}$ ].

$\nearrow$ The Suspect Foreigner is also a factor in the atmosphere of fear. Egypt is supported economically by Western countries, but those same countries' criticism of human rights breaches and authoritarian policies is construed by the authorities and loyalist media as "threats" against Egypt. This narrative finds resonance in parts of the Egyptian populace, already exhausted by too many crises and too much poverty. Foreign students and journalists find themselves in a very suspicious environment where their physical safety is sometimes threatened - the prime example being the murder of the Italian PhD student Giulio Regeni.

Journal of Arabic and Islamic Studies • 21 (2021) - Themed Section In2016: *353-*357 (C) Jacob Høigilt, Dept. of Culture Studies and Oriental Languages (IKOS), University of Oslo, NO 
Fear is to a great extent produced by fear-mongering, and it is not only Christians, Islamists and foreigners who are cast as threats, but any Egyptian opposed to the policies of the authorities. The media contributes to a sense of imminent threat against "simple" and "noble" Egyptian citizens who do their best to contribute to the country's economic and social well-being [ $\nearrow$ The Honourable Citizen]. On the celebration of the return of Sinai to Egypt on April 25, a columnist in one of the leading newspapers accuses various Egyptian opposition figures of wanting to destroy the country (al-HAWĀRĪ). One-time Muslim Brother 'Abd al-Mun 'im Abū l-Futūh, former director of the IAEA Muhammad al-Barādi '̄ì, and leftist leader Hamdīn Șabāḥ̄ have called for protests against the current regime and are therefore in cahoots with Egypt's enemies, "from Israel and Qatar, via Turkey, to the United States". The enemy is everywhere.

Even ordinary people and their pastimes awake fear among those who support Egypt's post-2013 political order: coffee shops are a threat to order and stability, according to one news report (al-SARRĀ $\breve{G}$ ). There are too many of them, they are not regulated, and they serve as gathering points for youth who have nothing to do. The young men who sit there day after day, brandishing their shisha mouthpieces, are a symbol of too little public regulation and monitoring, some think.

Against all these threats al-Sisi and the military cast themselves as protectors of Egyptians' security and well-being, and most of the media join in. Thus, when the Brothers call for demonstrations against the regime on November 11, a senior security official in Sohag tells people that the military is in full control, so they should just go about their business as usual and need not "fear" the demonstrations (A.SH.A.). President al-Sīsī nurtures an image as the protector of the nation, a vigilant guard against internal threats (Muslim Brothers and revolutionaries) as well as external ones (sinister foreign plots). It is not only political security al-Sisi and the military purportedly supply; social security is also an important field of official discourse [ $\nearrow$ Father Figures]. The pro-Sisi campaign "Protect your country" publishes a list in November of al-Sisi's achievements, and among the 39 items on the list are things like "solving the lack of gasoline" and "a million new apartments" ("ABD AL-RAHMĀAN) [ $\nearrow$ Apartment Wanted ]. The military brands itself as the nation's provider of food security and childcare [ $\nearrow$ Baby Milk].

The irony is that for many, the regime is exactly what they fear the most. Even as al-Sisi is busy building his one million apartments, stories surface about how the police acts as a mafia, confiscating rice and other goods belonging to shop owners (SAID). Personal security is also threatened - not just for opposition figures, but for anyone with bad luck, it seems: A wife and mother recounts her harrowing experience with the security apparatus when visiting Egypt after having lived abroad for some time: Miṣr laysat 'ummī (Egypt isn't my mother) (Huffpost).

The April $6^{\text {th }}$ movement talks about a "wall of fear" that needs to be breached and replaced by a wall of hope (Arabic $C N N)$. In a society as divided as Egypt's at this time, security becomes a zero-sum game. The regime fears criticism and unrest and clamps down on expressions of dissent or criticism that may raise public debate. For the revolutionaries who led the 2011 uprising, times are "bleaker than they have ever been," as one of them says in an interview with Die Zeit in December (BACKHAUS). The phenomenon of forced disappearances, widely mediatized this year (TRAFFORD \& RAMADHANI, MANSOUR),

jais • 21 (2021) - Themed Section In2016: *353-*357 
underscores the state's willingness to induce fear in people to retain political stability [ $\nearrow D$ Disappearances]. The zero-sum logic is not only about politics, but also about social conditions. The starkest illustration of the tension in social security is an ad posted on the official Facebook page of the upscale housing compound Beverly Hills outside Cairo (Beverly Hills Egypt). The ad consists of a picture of a couple lounging on the terrace by the swimming pool, surrounded by a lush lawn and decorative trees. A barbed-wire wall separates them from a slum area full of people looking enviously toward the other side [ $\nearrow$ Gated Communities / Compounds]. The caption reads: "Oh Lord be praised for the blessing of living in a sophisticated, civilized and safe way." The ad draws intense criticism on social media and is removed toward the end of the year.

In Tunisia, the fear of Islamist terrorism still lingers, after the attacks at the Bardo museum and in the tourist resort Sousse a year ago (TARFA). In January, the prosecution starts its case against a terrorist cell in the town of Chabbaou that facilitated the travel to Syria of young Tunisian jihadists (al-SHĀBBī). The large number of women in this cell attracts attention [ $\nearrow$ Male vs. Female]. In March, yet another violent confrontation with Islamist terrorists takes place in the border town of Ben Guerdane, leaving scores of people dead-most of them militants and Tunisian soldiers. A poll conducted in December shows that security issues and terrorism are on the top three list of worries for Tunisians (unemployment and economic crisis top the list) (IRI).

Not surprisingly, the threat of terrorism is an important theme in the public sphere. April 18 marks the $60^{\text {th }}$ anniversary of the founding of Tunisia's security forces, and the occasion is used to launch the campaign "Together, we defeat terrorism" (ZoomTunisia).

The fear of Islamist terrorism has led several intellectuals to prioritize security before human rights, and those liberal activists who see themselves as defenders of the democratic gains of the revolution are increasingly worried (Fanack). As former Prime Minister Moncef al-Marzouki (Munșif al-Marzūqī) notes in an op-ed for Foreignpolicy.com: "The current political elite has instead exploited the premise that security can only be achieved at the expense of human rights" (MARZOUKI).

\author{
Related Entries \\ ARRAYS - Apartment Wanted $\downarrow$ Baby Milk $\downarrow$ Clash $\downarrow$ Conversions $\downarrow$ Disappearances $\downarrow$ Father Figures \\ $\downarrow$ Gated Communities / Compounds $\downarrow$ The Honourable Citizen $\downarrow$ The Suspect Foreigner \\ CODES - Affluence $v s$. Destitution Male vs. Female \\ CODES ColLAPSED - True $=$ False $($ Life in Limbo)
}

\title{
References
}

\section{Written}

'ABD AL-RAHMĀN, 'Amr. “'Iḥmī [sic!] wațanak': 'injāzāt al-Sīsī khilāl 'āmayn ghayr masbūqa min sinīn." al-Ṭalī $a$, [n.d.], 2016, <https://www.altaly3anews.com/?p=126579> (last accessed December 20, 2018).

[Arabic $C N N=$ ] N.N. "Bi-jum'at 'al-'Arḍ hiya l-'irḍ',... al-Zumur: Furșa dhahabiyya, wa-6 'Abrīl: alYawm naqdir nabnī ’awwal țūba fỉ jidār al-'amal wa-nahdim jidār al-khawf.” ArabicCNN, April 15, 
2016, <https://arabic.cnn.com/middleeast/2016/04/15/egypt-6-april-movement-zumor> (last accessed December 20, 2018).

[A.SH.A.]. "Isti'dādāt 'amniyya mukaththafa li-muwājahat 'ayy țāri’ bil-muhāaazāāt qabl sā̄āt min 11/11." al-Mașrī al-Yawm, November 10, 2016, <https://www.almasryalyoum.com/news/details/ 1038435> (last accessed December 20, 2018).

BACKHAus, Andrea. "Der Polizeistaat ist zurück." Zeit Online, December 28, 2016, <https://www.zeit. de/politik/ausland/2016-12/aegypten-militaer-polizeistaat-revolution-rueckblick> (last accessed December 20, 2018).

[Beverly Hills Egypt =] N. N. "Yā rabb, laka l-ḥamd 'alà ni'mat al-sakan al-'āmin al-rāqī al-’ādamī." Facebook post, [n.d.], 2016, <https://m.facebook.com/Beverly.hills/photos/a.440387959421270. $1073741827.439977742795625 / 1059990480794345 /$ ?type $=3 \&$ theater $>$ (post was removed by 19 h15 on December 31, 2016).

$[$ Fanack $=]$ N. N. "Human Rights in Tunisia a Work in Progress." Fanack.com, August 17, 2016, $<$ https://fanack.com/tunisia/human-rights/human-rights-a-work-in-progress/> (updated March 12, 2018; last accessed December 20, 2018).

al-HAWĀRĪ, Dindrāwī. "al-Busațā̄ li-Ṣabāḥ̄ wa-'Abū l-Futūḥ wal-Barādiči: 'Naḥnu al-khayr wa-’antum

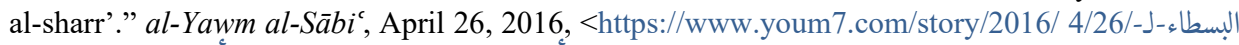

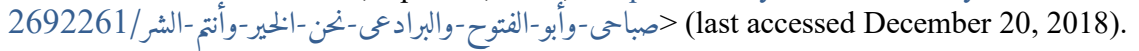

[Huffpost =] N. N. "Mișr laysat 'ummī!" Huffington Post, [n.d.], 2016, <http://www.huffpostarabi. com/sara-gamal-/story_b_10942598.html> (updated January 1, 2017; no longer active).

[IRI =] N. N. at Centre for Insights in Survey Research. "Sondage d'opinion publique auprès des Tunisiens 6 Décembre - 13 Décembre 2016." iri.org, [n.d.], 2016, <http:/www.iri.org/sites/ default/files/iri_francais_final_public.pdf> (updated November 30, 2018; last accessed December 20, 2018).

Kristianasen, Wendy. "Christians of the Orient: Egypt and the Future of the Copts." CounterPunch, December 26, 2016, <https://www.counterpunch.org/2016/12/26/christians-of-the-orient-egyptand-the-future-of-the-copts/> (last accessed December 20, 2018).

MANSOUR, Khaled. "Behind the sun: Is this the end of the rule of law in Egypt?" MadàMașr, February 14, 2016, <https://madamasr.com/en/2016/02/14/opinion/u/behind-the-sun-is-this-the-end-of-therule-of-law-in-egypt/> (last accessed December 20, 2018).

MARzouki, Mohamed Moncef. “The Grim Reality Behind Tunisia's Fairy Tale.” ForeignPolicy.com, September 22, 2016, <https://foreignpolicy.com/2016/09/22/the-grim-reality-behind-tunisiasfairy-tale-mohamed-moncef-marzouki/> (last accessed December 20, 2018).

$[M Y=]$ N. N. "Activists protest sectarian violence in Minya." EgyptIndependent, from Al-Masry alYoum, August 14, 2016, <https://www.egyptindependent.com/activists-protest-sectarian-violenceminya/> (last accessed December 20, 2018).

NA`̄̄M, Muhammad. "Marḥalat shaqq al-jidār: 'as'ila ḥawla 1-'awda lil-shāric'” MadàMașr, April 26,

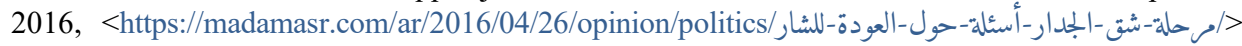
(last accessed December 20, 2018).

SAID, Nirvana. "State security 'crackdown on black market' = mafia-style confiscation of legal property." Facebook post, updated October 24, 2016, <https://m.facebook.com/story.php?story fbid=347648148907925\&id=100009882273086\&refid=28> (last accessed December 20, 2018).

al-SARRĀǦ, Aḥmad. 2016. "1.5 milyūn maqhan fī Miṣr dūn tarkhīṣ.” al-Wafd, January 11, > http://alwafd.org/تحقيقات-وحوارات/1014109-1-5-مليون-مقهى-في-مصر-دون-ترخيص" (last accessed December 20, 2018).

al-SHĀBBī, Șabāḥ. "Qaḍiyyat 'aḥdāth Shabbāw takshif: Hākadhā taḥawwala ḍābit al-jaysh 'ilà 'irhābī wa-hākadhā kānat al-’amwāl tursal min Turkiyā." al-Sabāḥ News, February 1, 2016, <http://www.

jais 21 (2021) - Themed Section In2016: *353-*357 
assabahnews.tn/article/1 قضية-أحداث-شّباو-تكشف-هكذا-تحول-ضابط-الجيش-الم-ارهابي-وهكنا- كانت-2017907 > الأموال -ترسل -من (last accessed December 20, 2018).

TARFA, Inel. 2016. "Witness: Bardo Tour Guide Remembers Attack." Tunisia-live, March 18, $<$ http://www.tunisia-live.net/2016/03/18/witness-bardo-tour-guide-recalls-attack/> (no longer active; last accessed in Evernote archive on December 20, 2018).

TRAFFORD, Robert and Mays RAMADHANI. 2016. "Ruled by fear: Egyptian government 'disappears' 1,840 people in just 12 months." Independent, March 10, <https://www.independent.co.uk/ news/ world/africa/egyptian-government-disappears-1840-people-in-just-12-months-ruling-by-feara6923671.html> (last accessed December 20, 2018).

[ZoomTunisia =] N. N. "Wazīr al-khārijiyya: shi'ār 'Ma'an naqụ̄i 'alà l-'irhāb' huwa da'wa mutajaddida li-takāthuf al-majhūdāt lil-qaḍā' 'alà l-'irhāb." ZūūmTūnīziyā, 18 April 2016, <http:// www.zoomtunisia.tn/article/top/33671.html> (last accessed December 20, 2018).

\section{Movies}

Condamné à l'espoir (Doomed to Hope). Short film by Youssef Ben Ammar. TN 2014.

Fawq mustawà al-shubuhāt. TV drama, written by 'Abd Allāh Hasan and Amīn Gamāl, Midhat al-'Adl (ishrāf drāmī) and Muḥammad Rajā’ (scenario), directed by Hānī Khalīfa. EG, Ramaḍān 2016.

Ghadwa hayy / Demain dès l'aube (Burning Hope). By Luṭī Āshūr (Lotfi Achour). TN 2016.

Ishtibāk (Clash). By Muhammad Diyāb (Mohamed Diab). EG, DE, F 2016.

Mawlānā (Our Master) / The Preacher. By Magdī Aḥmad 'Alī (Magdy Ahmed Ali). EG, U.A.E. 2016.

Nawwāra (Nawara). By Hāla Khalīl (Hala Khalil). EG 2016.

The Nile Hilton Incident. By Ṭāriq Șaliḥ (Tarik Saleh). EG, DE, SE, DK 2017.

al-Salāt wa'l-ma'raka / La Vallée du Sel (Prayer and Battle / The Valley of Salt). Documentary by Christophe Majdī Șābir (Magdy Saber). EG, CH 2016.

Zahrat Halab (The Flower of Aleppo). By Riḍà Bāhī (Ridha Behi). TN 2016.

\ jacob.hoigilt@ikos.uio.no 